\title{
こう配法による最適化制御系の安定*
}

\author{
寺 野 寿 郎**・塚 本 弥八 郎**

\section{Stability of the Optimalizing Control Systems by Gradient Method} \\ Toshiro Terano and Yahachiro Tsukamoto
}

The Gradient Method is the most basic one among the many optimalizing methods and has been studied rather theoretically. The reports of its practical applications are scarece, because there are many difficult problems which must be solved before appling it. There has been no kinetic analysis which shows the quantitative relations among the stability, the settling time, the effects of disturbances and the system-parameters such as the sampling interval, the process time lag, the height of test signal, the proportional gain of adjustment and so on.

This paper is concerned with the theoretical analysis, especially, for the stability problem.

It can be shown that the time lag in the process is a dominant factor on which the system stability depends, and that the stability also depends upon the initial condition since the system has an unstable limit cycle.

Finally some examples by analog simulation are given to examine the theoretical results.

\section{1. 緒言}

連続プロセスの最適化制御にはすでにいろいろな方 式1) 立が考光られているが，プラント効率がわずか上 昇すれば年間の経費節約が大きな額に達するような大 規模なプラントではこら配法5) による最適化制御がひ じょうに有効であると思われる.

こう配法は正確なプロセスモデルがわかっていない 場合や，あるいはモデルが既知でる未知の外乱が加わ るような系にも適用できるので確実さの点ですぐれて いる。しかし，これを実際のプロセスに応用しょらと すると, 理論面でも実際面でも多くの検討すべき問題 が残っているのに気付く.

本論文はこう配法による最適化制御に伴う問題を理 論的に検討したるので，特に対象となるプロセスに時 間おくれのある場合に，和くれの大きさ，サンプリン グ周期, 探索信号の大きさ, 比例動作のゲイン定数, 初期条件などが系の安定にどのような影響をおよぼす かを解析した。

ここで簡単のため 2 個のパラメータをもつプロセス を考光, その一つのパラメータは調節可能な操作量で あるが他方は未知の外乱であるとする.プロセスの評 価関数は定常状態ではこれらのパラメータの単峰性関

* 昭和 41 年 2 月 23 日受付

** 東京工業大学制御工学科
数であらわされ，過渡状態ではある時間沶くれを伴う ものとする.このような系は，すでに H. J. Kushner や S. S. L. Chang 辛) らによって解析され最適な制御動 作を与兄る関係が見いだされているが，これらはプロ 七スの拉くれが無視できる程度に小さいという仮定の もとで評価関数を計算している.

プロセスの怙くれを無視するということは，実際に は, 探索や操作のサンプリング周期をプロセスの時定 数に比べてじゅうぶん長くとるということを意味する が，これがあまり長いと山登りに時間がかかりすぎて， 外乱汶する速応性が悪くなる. 評価関数の傾斜の方 向を探索するだけならば，一時的逆応答のないかぎり サンプリング間隔をいくら短くしてもよさそうに思克 るが，実はプロセスにおくれがあると初期值が静特性 曲線上にないために不安定になる危険が多い。このよ らにプロセスの拈くれを考虑すると最適化制御に括け るサンプリング周期, 探索信号幅, 調節器の比例ゲイ ンなどは扔くれの時定数や外乱の特性によって適当に 選ばねばならないことがわかる。

\section{2. 基 本 式}

仮定

まずつぎのような仮定をおく。

（1）プロセス評価関数の特性は非線形の静特性と 線形の動特性の直列結合として表わされる。 


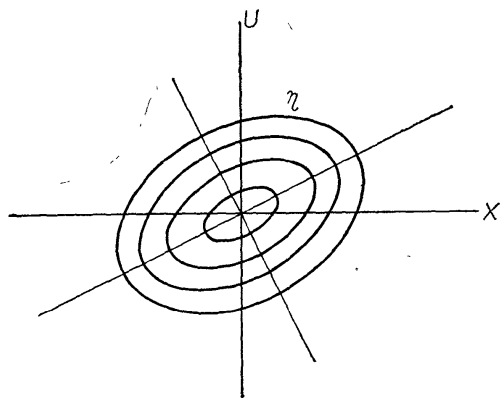

Fig. 1 Performance index

（2）評価関数は定常状態でだ円放物面で表わされ る (Fig. 1).

（3）評価関数の和くれは線形微分方程式で表わさ れる。

（4）外乱の変化ばサンプリング周期に比べてゆる やかである。

（5）プロセスの外乱に対する動特性と操作量に対 する動特性は同じである。

（6）評価関数の検出沶よび調節動作にはおくれは ない。

つぎにこれらの仮定の妥当性について検討する。

(1) の仮定はすべてのプロセスにあてはまるわけで はないが，取り扱いの便宜上このように考えた．化学 反応プロセスなどを除いてはだいたいこの仮定が満足 されると思われる。

（2）の仮定は評価関数が単峰で，その頂点付近だけ を問題にする場合はじゅうぶん妥当である。

(3) の仮定は通常のプロセスではつね許される.

（4）の仮定はとうぜんであり，もしこの仮定が許さ れないとすれば外乱はノイズと見なされ制御はできな w.

（5）および（6）の仮定は必ずしも必要でないが解 析の簡単化のために和いた。

本論文で用いたこう配法による制御動作はつぎのよ らなものである。

まず調整可能なパラメータ 変化させ，これによる評価関数值の変化量を時間 $T$ の 後に検出する，つぎにその変化量に比例して $x$ をステ

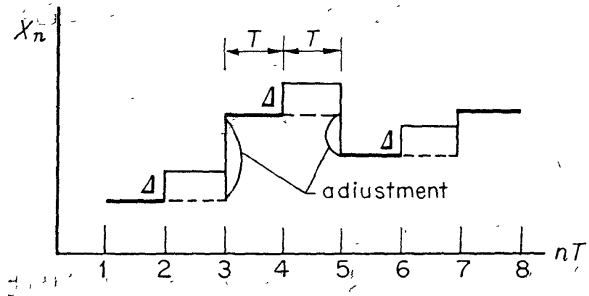

Fig. 2 Adjust procedure

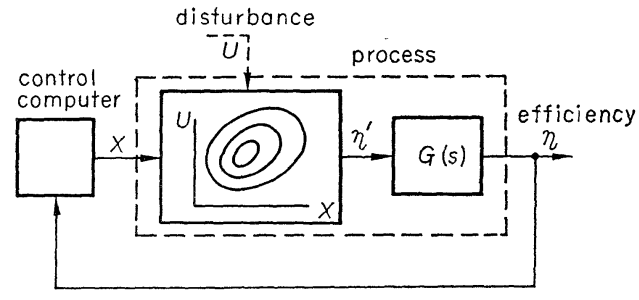

Fig. 3 Block diagram

ップ状に調整しつぎの時間 $T$ だけその状態を保つ.こ の動作は Fig. 2 に示すように時間 $2 T$ ごとに繰り 返えされる。調節動作はその探索の直前の評価関数値 の差に比例するだけでなく，過去のいくつかの值の線 形結合であってもよい，これは通常の制御動作の PD あるいは $\mathrm{PD}^{2}$ 動作に対応する。

上述の仮定にしたがって制御系のブロック線図を作 ると Fig. 3 のよらになる. 制御用計算機には数值計 算部, 論理演算部, メモリ，サンプラおよびホールダ が含まれる．図中点線で囲った部分は制御対象で仮定 により操作量 $x$ と外乱 $U$ の非線形関数であらわされる 静特性から定常評価関数 $\eta^{\prime}$ が定まる。 $\eta^{\prime}$ が定まると 線形伝達関数 $G(s)$ による抢くれを経て過渡的評価関 数クがきまる。ここで $\eta^{\prime}$ は最適化制御系で最大に保 ちたい量であるが，われわれがプロセスの出力として 実際検出できるのはクだけであって，グがどのように なるか梳わかない。

記 号

いま記号をつぎのように定める。

$A, B, C=$ positive constants

$a_{1}, a_{2}, b_{1}, b_{2}=$ constants

$D=\exp \left(-T / T_{p}\right)$

$D_{1}=\exp \left(L / T_{p}\right)$

$H_{m}=$ a linear function of $Y_{m}{ }^{\prime} \mathrm{s}$

$K=$ proportional gain of adjustment

$L=$ dead time of process

$P=$ D. C. Component of the input to $N(z)$

$Q=$ Amplitude of sinusoidal oscillation $x=$ adjustable parameter

$x_{n}=$ the value of $x$ at $n$th sampling interval

$E=$ amplitude of limit cycle

$G(z)=z$-transform of linear part

$N(z)=$ discrete describing function of nonlinear part

$X_{m}=x_{m}+\Delta / 2$

$Y_{m}=\eta_{m}-\eta_{m-1}$

$Y_{m}^{\prime}=\eta_{m}^{\prime}-\eta_{m-1}{ }^{\prime}$

$T=$ sampling interval 
$T_{p}=$ time constant of process

$U=$ disturbance

$m, n=$ running indexes (positive integer)

$z=z$-transform variable $=\exp (2 T s)$

$\eta=$ performance index (efficiency)

$\eta^{\prime}=$ performance index in steady state

$\Delta=$ test signal for seeking the peak

$\phi=$ phase difference between sampling instant and sinusoidal oscillation $=0 \sim 1$

\section{基 礎 式}

仮定式（2）から定常状態のプロセスの方程式はつ ぎのようになる。

$$
\eta_{m}{ }^{\prime}+A\left(x_{m}-B U_{m}\right)^{2}+C U_{m}^{2}=0
$$

ここに $A, B, C$ は正の定数で，また $\eta^{\prime} ， x$ 执よび $U$ は $\eta^{\prime}$ の頂点が原点にくるように正規化してある。

プロセスの運動方程式はサンプリング時刻のみに注 目すれば線形差分方程式に変換される。いまプロセス を二次和くれ系とすれば動特性は次式であらわされる。

$\eta_{m}+b_{1} \eta_{m-1}+b_{2} \eta_{m-2}=a_{1} \eta_{m-1}{ }^{\prime}+a_{2} \eta_{m-2}{ }^{\prime}$

ただし $a_{1}, a_{2}, b_{1}, b_{2}$ は定数.

（1），(2）式はそれぞれ，プロセスの静特性と動特 性をあらわし，両者から $\eta^{\prime}$ を消去すればプロセス特 性が得汉れる、つぎに制御装置の式は，添字 $m$ が偶数 か奇数石異なり， $\Delta$ を探索信号幅，Kを調節動作の比 例ゲインとすれば,

$$
\begin{aligned}
& x_{2 n-1}-x_{2 n-2}=\Delta \\
& x_{2 n}-x_{2 n-2}=K\left(\eta_{2 n}-\eta_{2 n-1}\right) / \Delta
\end{aligned}
$$

（3）式は頂点の探索動作をあらわし，（4）式は調 節動作をあらわしている.

(1)〜（4）式がここに取り扱ら最適化制御系の基 本方程式である.

\section{3. 解 析}

\section{特性方程式}

$Y_{m}$ および $Y_{m}^{\prime}$ をつぎのよらに定義する.

$$
\begin{aligned}
& Y_{m}=\eta_{m}-\eta_{m-1} \\
& Y_{m}{ }^{\prime}=\eta_{m}{ }^{\prime}-\eta_{m-1}{ }^{\prime}
\end{aligned}
$$

これらの新しい変数を用いて（1）式を書き直すと

$$
Y_{m}{ }^{\prime}+A\left(x_{m}-x_{m-1}\right)\left(x_{m}+x_{m-1}-2 B U_{m-1}\right)=0
$$

な拈，ここでは(4)の仮定にしたがっって， $U_{m} \risingdotseq U_{m-1}$ としてある。

いま $Y_{m}$ の奇数番目の項を $(2)$ 式より消去すると

$$
\begin{aligned}
& H_{2 n+1}-b_{1} H_{2 n}+b_{2} H_{2 n-1} \\
& \quad=Y_{2 n+2}+\left(2 b_{2}-b_{1}^{2}\right) Y_{2 n}+b_{2}{ }^{2} Y_{2 n-2}
\end{aligned}
$$

$$
H_{m}=a_{1} Y_{m}^{\prime}+a_{2} Y_{m-1}^{\prime}
$$

(4), (7), (8),（9）式から $Y_{m}^{\prime}, Y_{2 n}$ の項を消 去すると, つぎのような $X_{2 n}$ に関する差分方程式を 得る。

$$
\begin{aligned}
& X_{2 n+2}+\left\{A K\left(2 a_{1}-a_{2}+a_{1} b_{1}\right)\right. \\
& \left.+\left(2 b_{2}-b_{1}^{2}-1\right)-2 A K B U_{2 n-1}\left(a_{2}-a_{1} b_{1}\right) / \Delta\right\} X_{2 n} \\
& +\left\{A K\left(2 a_{1} b_{2}-2 a_{2} b_{1}-a_{2}+a_{1} b_{1}-a_{2} b_{2}\right)\right. \\
& +\left(b_{2}{ }^{2}-2 b_{2}+b_{1}^{2}\right) \\
& +2 A K B U_{2 n-1}\left(a_{2}-a_{1} b_{1}\right) / \Delta \\
& \left.+2 A K B U_{2 n-3} a_{2} b_{2} / \Delta\right\} X_{2 n-2} \\
& -\left\{A K a_{2} b_{2}+b_{2}{ }^{2}-2 A K B U_{2 n-3} a_{2} b_{2} / \Delta\right\} X_{2 n-4} \\
& -2 A K B\left\{a_{1} U_{2 n}-\left(a_{2}-a_{1} b_{1}\right) U_{2 n-1}\right. \\
& \left.+\left(a_{1} b_{2}-a_{2} b_{1}\right) \cdot U_{2 n-2}-a_{2} b_{2} U_{2 n-3}\right\} \\
& +\left(X_{2 n}{ }^{2}-X_{2 n-2}{ }^{2}\right) \cdot A K \cdot\left(a_{2}-a_{1} b_{1}\right) / \Delta \\
& +\left(X_{2 n-2}{ }^{2}-X_{2 n-4}{ }^{2}\right) A K a_{2} b_{2} / \Delta=0 \\
& \text { ただし上式で } \quad \cdots(10) \\
& \quad X_{m}=x_{m}+\Delta / 2
\end{aligned}
$$

とおいた。この方程式を解けば系の全挙動が明らかに なるゆえ（10）式はいわばこの系の特性方程式である. しかし，これは非線形項をふくんでいるから解析的に 解くのはひじょらに困難である。外乱Uの変動が無視 できる程度に小さい場合は記述関数法 ${ }^{8) 97}$ あるいは位 相面法 ${ }^{10)}$ により系の安定性が解析でき，また過渡状態 のだいたいの様子もわかる，プロセスの括くれが高次 のときは特性方程式はひじょらに複雑となる。しかし， 和くれを一次と仮定してもプロセスの時間和くれが安 定性におよぼす影響はじゅうぶん知ることができるの で，以下の解析では，プロセスの报くれを一次拉くれ とさだ時間で近似し，かつ外乱がない場合について検 討する。

このとき（2）式の係数はつぎのようになる.

$$
a_{1}=1-D_{1} D, \quad b_{1}=-D, \quad a_{2}=b_{2}=0
$$

ただし $\left.D=\exp (-T\} T_{p}\right), D_{1}=\exp \left(L / T_{p}\right)$

また $T$ は探索のサンプリング周期の $1 / 2$

$T_{p}$ はプロセスおくれの時定数,

Lはそのさだ時間である。

特性方程式 (10) 式はつぎのよらに簡単になる。

$X_{2 n+2}+\alpha X_{2 n}+\beta X_{2 n-2}+\gamma\left(X_{2 n^{2}}-X_{2 n-2}{ }^{2}\right)=0$

ただし

$$
\begin{aligned}
& \alpha=2 A K\left(1-D_{1} D\right)-A K D\left(1-D_{1} D\right)-1-D^{2} \\
& \beta=D^{2}-A K D\left(1-D_{1} D\right) \\
& \gamma=A K D\left(1-D_{1} D\right) / \Delta
\end{aligned}
$$

\section{安定の必要条件}

(12）式で表わされる系の安定問題を考えるのにま ずその必要条件として線形な部分の安定条件を求めて おく. 線形差分方程武 


$$
X_{m+2}+\alpha X_{m+1}+\beta X_{m}=0
$$

の安定条件は, 特性方程式

$$
z^{2}+\alpha z+\beta=0
$$

の根の絶対値が 1 より小さいことから求まる.

$\therefore 1+\alpha+\beta>0,1-\alpha+\beta>0,1-\beta>0$

むだ時間がないとさは，条件はつぎのようになる。

$$
1+D^{2}>A K(1-D)
$$

これからたと党ば $A K=1.5$ のとき

$$
1>D>0.28 \quad \therefore 0<T / T_{p}<1.27
$$

また $0<A K \leqq 1$ なら (15) 式はつ放に満足される. 条件 (15) 式は系が安定なための必要条件であるが(12) 式は非線形差分方程式であるからその安定性は係数の 值だけでなく初期条件にも依存する。つぎにこれを考 えよう。

\section{非線形部の記述関数}

$X_{m}$ の絶対值が大きくなると (12) 式の非線形項は ひじょらに大きくなる。したがって（12）式であらわ される系は不安定なリミットサイクルを持つことが予 想される.これを記述関数法で求めるために特性方程 式を線形部と非線形部に分割してブロック線図で示す と，Fig. 4 のようなサンプル值制御回路を得る。た だし，この図ではサンプリング周期を $2 T$ として伝 達関数を書いてある.

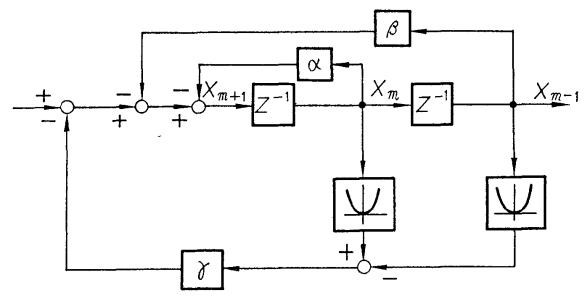

Fig. 4 Block diagram (1)

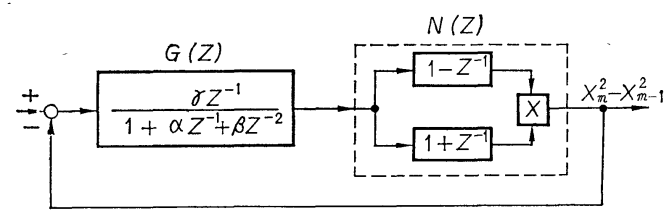

Fig. 5 Block dịagram (2)

さらにこれを書き直すと Fig. 5 のように線形部 $G(\boldsymbol{z})$ と, 乗算をふくんだ非線形部 $N(\boldsymbol{z})$ が直列結合 した閉ループになる。

ここで非線形部 $N(\boldsymbol{z})$ の記述関数を考えよう. $N^{\prime}(\boldsymbol{z})$ の入出力信号をそれぞれ $x_{n}, y_{n}$ とし， $x_{n}$ がつぎのよ らな正弦波であるとする。

$$
x_{n}=P+Q \sin \left(4 \pi T / T_{c}\right)(n+\phi)
$$

ただし， $T_{c}$ はリミットサイクルの周期で， $n$ は整数 である。また фはサンプリング周期とリミットサイク
ルの周期との間の位相差で 0 から 1 をでの任意の值を 取りうる. $P$ は入力信号の直流成分で, $Q$ は $N(z)$ の入口に欮けるリミットサイクルの振幅である.

このとき出力はつぎのようになる。

$$
\begin{aligned}
y_{n} & =\left(x_{n+1}+x_{n}\right)\left(x_{n+1}-x_{n}\right) \\
& =Q^{2} \sin 4 \pi T / T_{c} \cdot \sin \left(4 \pi T / T_{c}\right)(2 n+2 \phi+1) \\
& +4 P Q \sin 2 \pi T / T_{c} \cdot \cos \left(4 \pi T / T_{c}\right)(n+\phi+1 / 2)
\end{aligned}
$$

(18）式の $y_{n}$ は直流分を含まないから，一巡ルー プを考光ると $x_{n}$ にも直流分はない。すなわち $P=0$ である、したがって

$$
y_{n}=Q^{2} \sin 4 \pi T / T_{c} \cdot \sin \left(4 \pi T / T_{c}\right)(2 n+2 \phi+1)
$$

けっきょく, $N(z)$ の出力は入力の 2 倍の高調波の みとなる。

このように入出力信号の周波数が異なるときは一般 に記述関数法は使用できないが，サンプル值系ではサ ンプル時点のみに着目すれば高調波を等価的に基本波 と見なせる場合がある。まずリミットサイクルの周期 $T_{c}$ が探索周期 $2 T$ の偶数倍の場合を考兄よう.

このときは $\quad T_{c}=4 m T, \quad(m=1,2, \cdots)$

$\therefore \sin 4 \pi T / T_{c}=0$, 寸なわち $y_{n}=0$ となって持続 振動は存在しない。

つぎとリミットサイクルの周期が探索周期の 3 倍の 場合には

$$
\begin{aligned}
& T_{c}=6 T \\
& \sin 4 \pi T / T_{c}=\sqrt{3} / 2 \\
& \therefore \quad y_{n}=(\sqrt{3} / 2) Q^{2} \sin (2 \pi / 3)(2 n+2 \phi+1)
\end{aligned}
$$

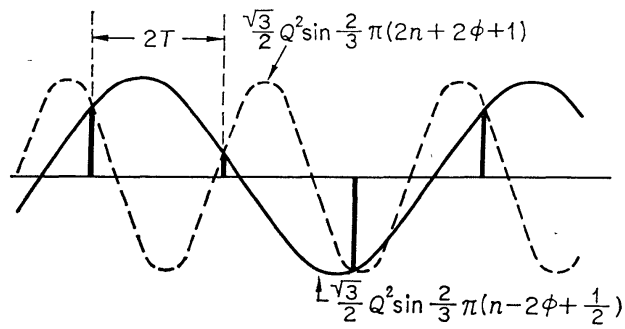

Fig. 6 Output signal of $N(z)$

この場合にかぎり Fig. 6 に示されるように（20) 式はつぎのような基本周波振動に書き直すことができ る.

$$
y_{n}=(\sqrt{3} / 2) Q^{2} \sin (2 \pi / 3)(n-2 \phi+1 / 2)
$$

すなわち，この場合はリミットサイクルが存在しうる。

振動周期が探索周期の 5 倍以上の奇数倍の場合には このように高調波と等価な基本周波が存在しない，け っきょく、リミットサイクルが存在するときは，その 
周期は必ず探索周期の 3 倍でなければならない。

(17）执よび (21) 式から記述関数はつぎのように なる。

$$
\left\{\begin{array}{l}
|N(z)|=\frac{\sqrt{3}}{2} B \\
\angle N(z)=2 \pi \phi-\pi / 3
\end{array}\right.
$$

ここに $\phi=0 \sim 1$ であるから， $\angle N(z)$ は $300^{\circ}$ から -60 までの任意の值をとれる。したがってゲイン条 件さえ満足すればりミットサイクルは起こりらる.

このときの線形部のゲインを計算する.

$T / T_{c}=1 / 6$ から $\omega=\pi / 3 T$ であるから

$$
\left\{\begin{array}{l}
z=e^{2 S T}=e^{2 \pi j / 3}=-\frac{1}{2}+j \frac{\sqrt{3}}{2} \\
z^{-1}=-\frac{1}{2}-j \frac{\sqrt{3}}{2}
\end{array}\right.
$$

したがって

$$
\left|G(j \omega)_{\omega=\pi / 3 T}\right|=\frac{\gamma}{\sqrt{\alpha^{2}+\beta^{2}+1-\alpha \beta-\alpha-\beta}}
$$

(22) 打よび (23) 式からリミットサイクルの振幅は

$$
Q=\frac{2}{\sqrt{3}} \cdot \frac{\sqrt{\alpha^{2}+\beta^{2}+1-\alpha \beta-\alpha-\beta}}{\gamma} .
$$

となる。

\section{4. 安 定 限 界}

(24) 式から安定限界時の $Q\left(x_{m}\right.$ の初期值に相当), $D, \Delta, A K$ などの関係を計算すると Fig. 7 の実線の ようになる.斜線で示した部分が安定領域である. $A K=1.5$ の曲線が途中で縱線で切れているのはこの 点で (16) 式の条件にかかるからである.

この㘠によるとプロセスにおくれがない場合，すな

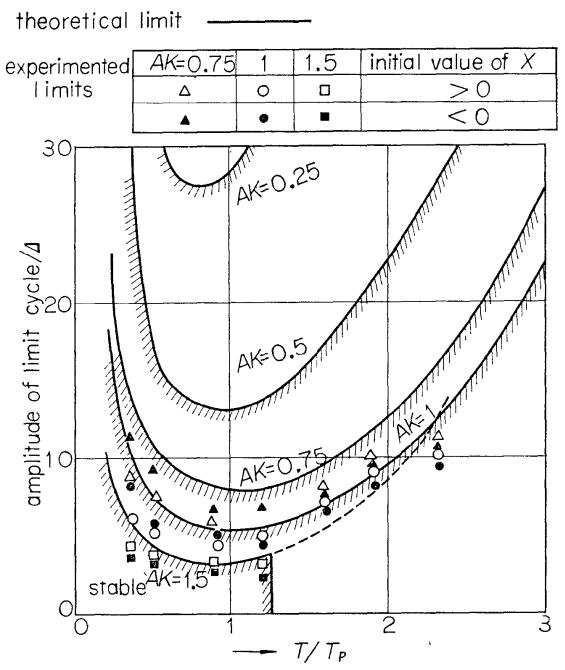

Fig. 7 Stability limit
わち $T_{p}=0$ のときには $A K<1$ ならつね沈安定だが， おくれがあると同じゲインでも初期值いかんでは不安 定になることがわかる．またおくれが大きいと $A K>$ 1 に選んでも初期值か頂上近傍にある場合（あるいは 探索信号幅 $\Delta$ が大きい場合）には安定に頂上へ達しう ることが示されている、これは打くれのために探索結 果が実際よりもずっと少なく出てくるからである.

以上の結果を確かめるために数值例について, 初期 条件を変えて基本式を計算した結果を位相面上の軌跡 として Fig. 8 亿示す. 図に四角に囲ってある線は (24) 式から求めたりミットサイクルの振幅の計算值 で，初期条件がこの内側にあれば安定である．記述関 数による安定限界が注添正しいことがわかる.

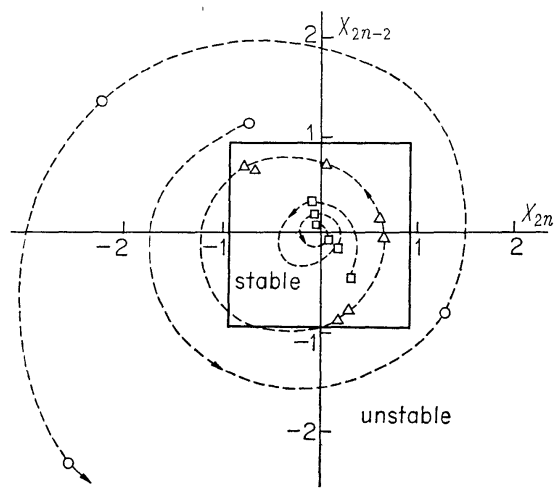

$A K=1, \quad T / T_{p}=2$

Fig. 8 Trajectories on phase plane

5. アナログシミュレーション

以上の理論解を確かめるためアナログシミュレータ による実験を行なった。

基本式（1）～(4) は Fig.9 のような回路によっ てアナログ計算機で実現できる ${ }^{11)}$.

プロセスの線形部と非線形部はアナログ計算機で組 み，これに $\mathrm{H}_{1} \sim \mathrm{H}_{4}$ のホールド回路を付加して制御動

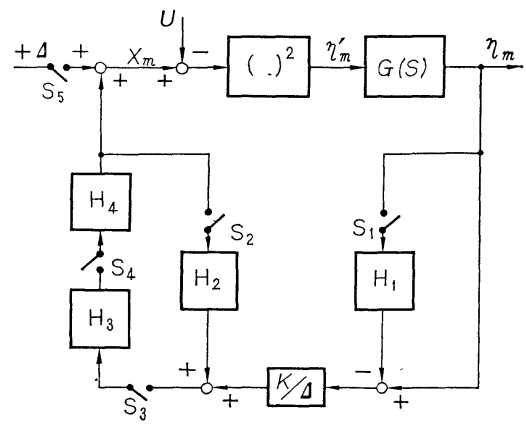

$\mathrm{S}$ : switch, $\mathrm{H}$ : holder

Fig. 9 Analogue simulation 
作をシミュレートさせる.ホールド回路の開閉は別に 設けたパルス発振器によって行なう。

Fig. 9 のアナログ回路に批りる制御動作を説明す るとまず $\mathrm{H}_{4}$ 飞 $X_{2 n-2}$ がホールドされたところから 始めると, $H_{4}$ はつぎの $2 T$ 時間 $X_{2 n-2}$ をホールド する. $T$ 時後に $\eta_{m}$ の值は $\eta_{2 n-1}$ となり，この值を $\mathrm{S}_{1}$ でサンプリングしてつぎの $2 T$ 時間 $\mathrm{H}_{1}$ にホール ドする．それと同時に $\mathrm{S}_{2}, \mathrm{H}_{2}$ が $\mathrm{H}_{4}$ にホールドされて いる $X_{2 n-2}$ をサンプリングし $2 T$ 時間ホールドする.

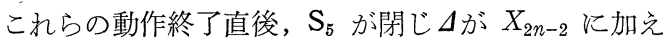
られ $X_{2 n-1}$ ，となる.4が加光られてから $T$ 時間後に は $\eta_{m}$ は $\eta_{2 n}$ となっているが $\mathrm{H}_{1}, \mathrm{H}_{4}$ には $\eta_{2 n-1}$, $X_{2 n-2}$ がホールドされたままでいるから，その瞬間に $\mathrm{H}_{3}$ がサンプリングホールドすれば（4）式を満足す る $\mathrm{X}_{2 n}$ が $\mathrm{H}_{3}$ にたくわ兄られることになる。

その後 $\mathrm{H}_{4}$ が $X_{2 n}$ をサンプリングしてつぎの $2 T$ 時間ホールドし，それと同時に $S_{5}$ が開く，これらの 一連の動作が繰り返される。また初期值は（1）式で 与兄られる静特性曲線上飞あるものとし, $\mathrm{H}_{3}$ に $X_{0}$ の值をホールドすることによって与兄られる.

以上のアナログシミュレーションにより, 調節器の 比例ゲイン，サンプリング周期，初期值を変化させて 得られた制御経過の例を Fig. 10 版よ゙ Fig. 11 に 示す. Fig. 10(A), (B) はほぼ持続振動状態にある二
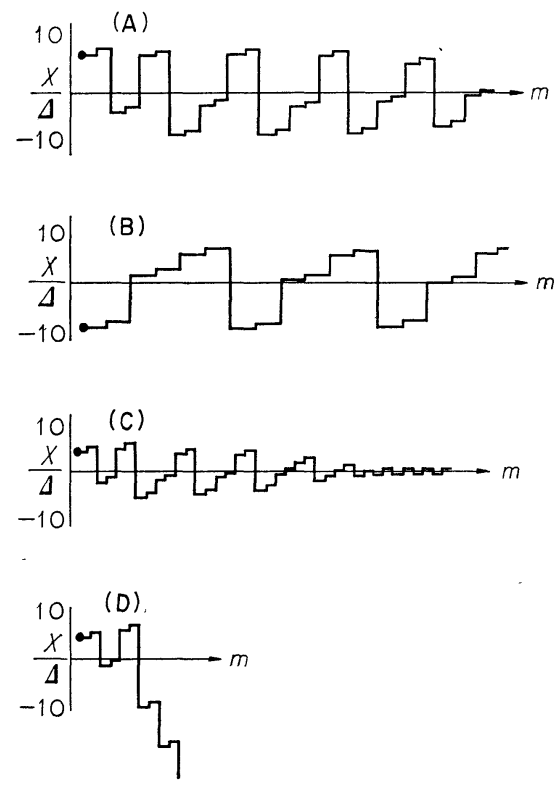
(A) $A K=0.75, T / T_{p}=1.60, X / \Delta=8.5$
(B) $A K=1.0, T / T_{p}=2.3, \quad X_{0} / \Delta=-9.0$
(C) $X_{0} / \Delta=4.5, A K=\mathrm{I} .0, T / T_{p}=0.9$
(D) $X_{0} / \Delta=5.0, \quad$ initial condition

Fig. 10 Performances of simulator (1)

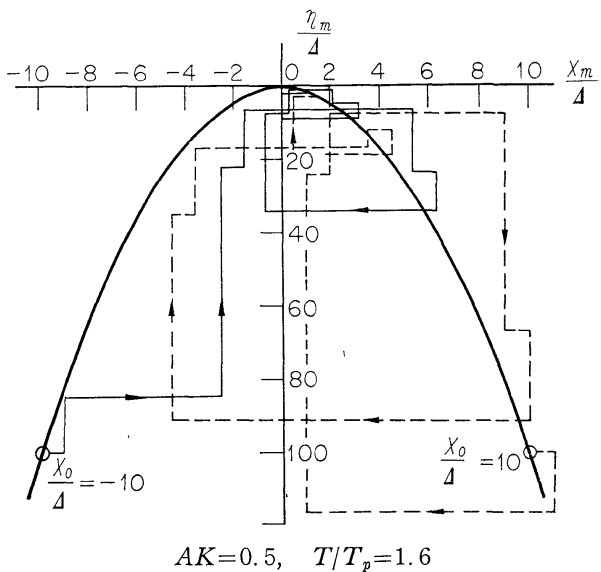

Fig. 11 Performances of simulator (2)

つのケースを $x_{m}$ について記録したものでまた $(\mathbf{C})$ ， (D) は同一システムでも初期条件の違いにより，ある いは発散し，あるいは収れんすることを示す。

Fig. 11 は $x_{m}$ と $y_{m}$ とそついて制御経過を X-Y レコーダに記録したもので，時間おくれのため $\eta_{m}$ が 静特性から大きくはずれる状流がよくわかる。

上述のようなシミュレーションを数多くのパラメー 夕について行ならと安定限界が求められる. Fig. 7 に 記した各点は $A K=0.75,1,1.5$ の場合について実 験的に求めた安定限界である. 記述関数による理論と ほぼ一致しているが，実測值のほうが全体的にやや小 さいこれはリミットサイクルを正弦波の振幅で示し たためと考光られる。

すなわち Fig. 10 の（a）（b）の場合の波形を見 ても明らかなように, 正弦波の最大值とサンプル值の 最大值とは必ずしも一致しない。したがって初期值は 正弦波の振幅よりもやや小さい值となり上の結果が生 じたのである.

\section{6. 結言}

以上の解析および実験によりこう配法による最適化 制御系を構成する場合に, プロセスの括くれを無視し てサンプリング周期, 探索信号幅㐨よび比例ゲインの 大きさなどを決めると不安定になる危険が多く，打く れの特性を考慮してこれらのパラメータを適当に選定 しなけ札ばなないことがわがった。

今後, さらに高次の扰くれやその補償法について検 討してゆく予定である。また外乱やノイズの影響を調 ベつつある.

このアナログシミュレーションによる実験は東工大 大学院学生程塚, 小池両君によるものである.また有 益なご意見をくださった森田助教授に感謝する。 


\section{文献}

1) D. G. Wilde: Optimum Seeknng Methods (Prentice Hall Inc. -1964)

2) Y.T.Li \& C.S Draper: Prınciples of Optimızing Control System and an Application to the Internal Combustion Engine (ASME Publication 1951.9)

3) S. Fujii \& N. Kanda: An Optımalizıng Control of Bioler Efficiency, Automatic and Remote Control, Proc. 2 nd IFAC Congress p. 380

4) 近藤交治 : 最適化制御の動向, 機学誌 (1963 年 3 月) p. 319

5) C. B. Tompkins : Method of Steep Descent, Modern Mathematics for the Engineers, Vol. 1, Chap. 18, (McGraw Hill-1956)

6) H.J Kushner : Hill Clımbing Methods for the Optimization of Multi-Parameter Norze Disturbed
Systems, Trans. ASME (June, 1963) p. 157

7) S. S. L. Chang: Optimization of the Adaptive Function by $z$-Transform Method, Trans. AIEE (July, 1960) p. 223

8) C. K. Chow: Contactor Servomechanisms Employing Sampled Data, Trans. AIEE (March, 1954) p. 51

9) B.C.Kuo: Design of Relay Type Sampled Data Control Systems Using Discrete Describing Function, IRE, Convention Records (1962) p. 99

10) J. A. Aseltine, R. A. Nesbit : The Incremental Phase Plane for Nonlinear Sampled Data Systems, IRE Trans, AC-5, (Aug. 1960) p. 159

11）小池常雄：最適化制御系のシミュレーション，東工大 卒論 (1966 年 3 月)

Vol. 2 No. $2(1966-6)$ 正誤表

$<$ 伊沢 - 古田 ·大野 - 井藤 - 秋山 : Binary Random Signal に よる熱交換器の動特性試験>

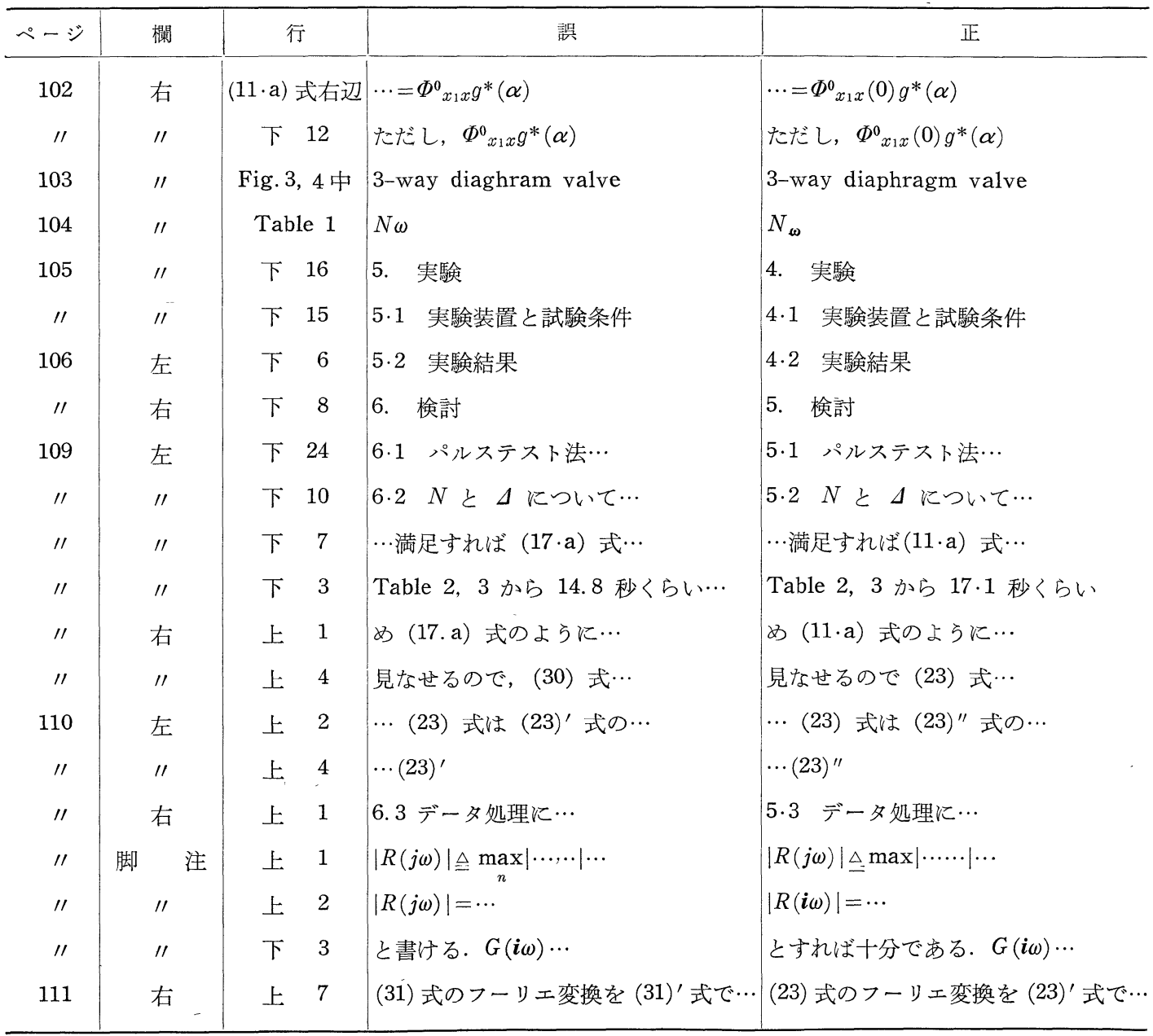

